University of Nebraska - Lincoln

DigitalCommons@University of Nebraska - Lincoln

Faculty Publications: Department of Entomology

2006

\title{
An Update on the Distribution and Diversity of Bombus in Nebraska (Hymenoptera: Apidae)
}

Douglas A. Golick

University of Nebraska-Lincoln, dgolick2@unl.edu

Marion D. Ellis

University of Nebraska-Lincoln, mellis3@unl.edu

Follow this and additional works at: https://digitalcommons.unl.edu/entomologyfacpub

Part of the Entomology Commons

Golick, Douglas A. and Ellis, Marion D., "An Update on the Distribution and Diversity of Bombus in Nebraska (Hymenoptera: Apidae)" (2006). Faculty Publications: Department of Entomology. 183. https://digitalcommons.unl.edu/entomologyfacpub/183

This Article is brought to you for free and open access by the Entomology, Department of at DigitalCommons@University of Nebraska - Lincoln. It has been accepted for inclusion in Faculty Publications: Department of Entomology by an authorized administrator of DigitalCommons@University of Nebraska - Lincoln. 


\title{
An Update on the Distribution and Diversity of Bombus in Nebraska (Hymenoptera: Apidae)
}

\author{
Douglas A. Golick and Marion D. Ellis \\ Department of Entomology, University of Nebraska-Lincoln, \\ Lincoln, Nebraska 68583-0816
}

\begin{abstract}
From 1999-2002, the University of Nebraska Department of Entomology, Folsom's Children Zoo, and Lincoln Public Schools Science Focus High School initiated a program called Bumble Boosters. Forty schools participated to conduct a general survey of Nebraska bumble bees to: 1) determine whether the 20 species of bumble bees previously identified can still be found in Nebraska, 2) collect in areas that were not included in previous surveys, and 3) discover any additional species in the state. This study provides an update to previous surveys including; new distribution maps for species, and a discussion of findings.

KEY WORDS: Bombus, new distribution records (Nebraska)
\end{abstract}

The last in-depth annotated list of Nebraska bumble bees was published by Laberge and Webb (1962). They included 20 species of Bombus recorded in Swenk's (1907) paper, the University of Nebraska State Museum holdings, and the personal collection of M.C. Webb. Since LaBerge and Webb's (1962) study, the ecological landscape of the state has changed, including: the loss of nesting habitat and forage plants to urbanization, introduction of non-native plant species, increased planting of row crops in the central portion of the state, and declines in managed and feral honey bee populations (NASS, 2005). Due to the changes in Nebraska's landscape and the interval since bumble bees were last surveyed in the state, we felt it important to conduct an update to LaBerge and Webb's (1962) survey.

In 1999, the University of Nebraska Department of Entomology, Folsom's Children Zoo, and Lincoln Public Schools Science Focus High School initiated a program called Bumble Boosters (Golick and Ellis, 2003). Thirty six schools and four institutions participated to conduct a general survey of Nebraska bumble bees to: 1) determine whether the 20 species of bumble bees previously identified can still be found in Nebraska, 2) collect in areas that were not included in previous surveys, and 3) discover any additional species in the state. The collection records gathered during this project are presented in this paper.

\section{Materials and Methods}

The Bumble Boosters team was comprised of 36 Nebraska high schools, the University of Nebraska-Kearney, Chadron State College, and Wildcat Hills Nature Center, and was led by the University of Nebraska-Lincoln Department of Entomology. Since a majority of the participants were novices in bumble bee identification, the authors conducted training workshops to teach participating teachers how to identify bumble bees. In order to determine the diversity of bumble bee species in their area, participating schools were instructed to collect bumble bees at multiple intervals from March to October, in 2000 and 2001. Participants recorded collection data for each specimen on data sheets provided by the authors. Each bumble bee specimen was labeled with collection location, date, collector's name, floral record and species identification (given by student or teacher). An 


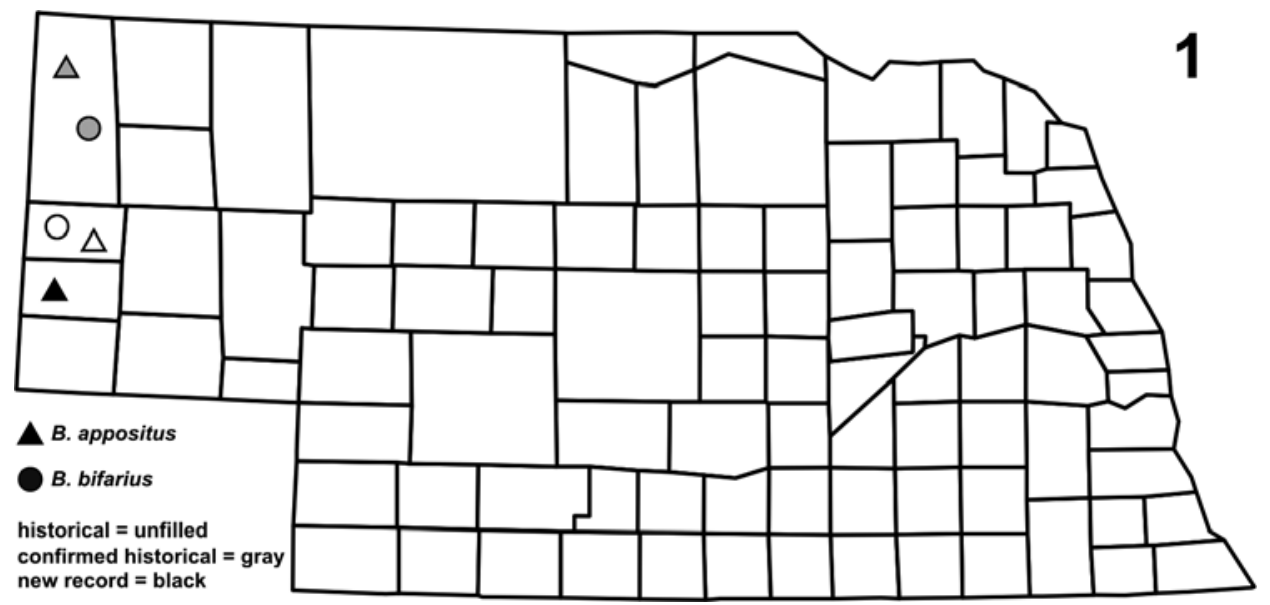

Figs. 1-8. Historical = county records presented in Swenk (1907) and LaBerge and Webb (1962), confirmed historical $=$ those county records reported in Swenk (1907) and LaBerge and Webb (1962) and recollected in this study, new record $=$ new county records established by this study. Nomenclature follows Williams (2005).

additional unique number was assigned to each specimen that matched a corresponding record on the data sheet. Schools used the Bumble Boosters: A Guide to the Identification of Nebraska Bumble Bee Species (Golick and Ellis, 2000) to identify specimens.

All specimens were mailed to the University of Nebraska-Lincoln (UNL) for species identification confirmation (conducted by the authors), and data were recorded in a Filemaker Pro $^{\mathrm{TM}}$ database (Filemaker, Inc). Misidentified specimens were given corrected species identification labels. Specimens of interest from schools were retained and added to the project collection, held in the UNL Department of Entomology. The majority of common specimens were returned to participants. In addition to the specimens submitted by schools, the authors also made several collecting trips from 1999-2002. These collecting trips were necessary to cover areas with no cooperators and to include

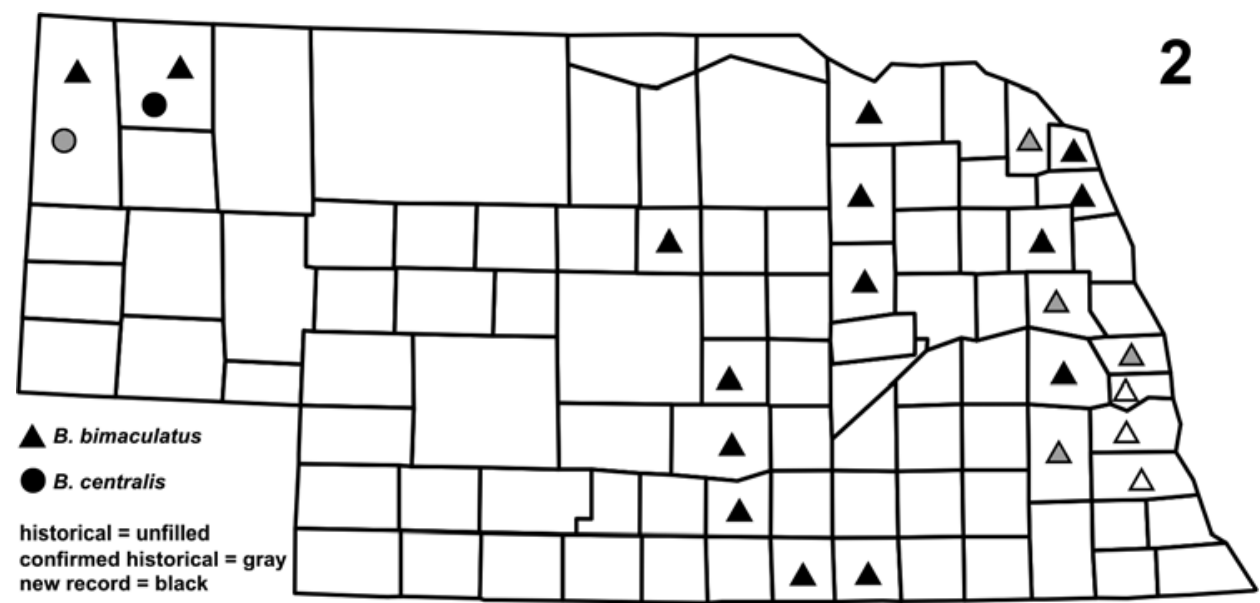

Figs. 1-8. Continued. 


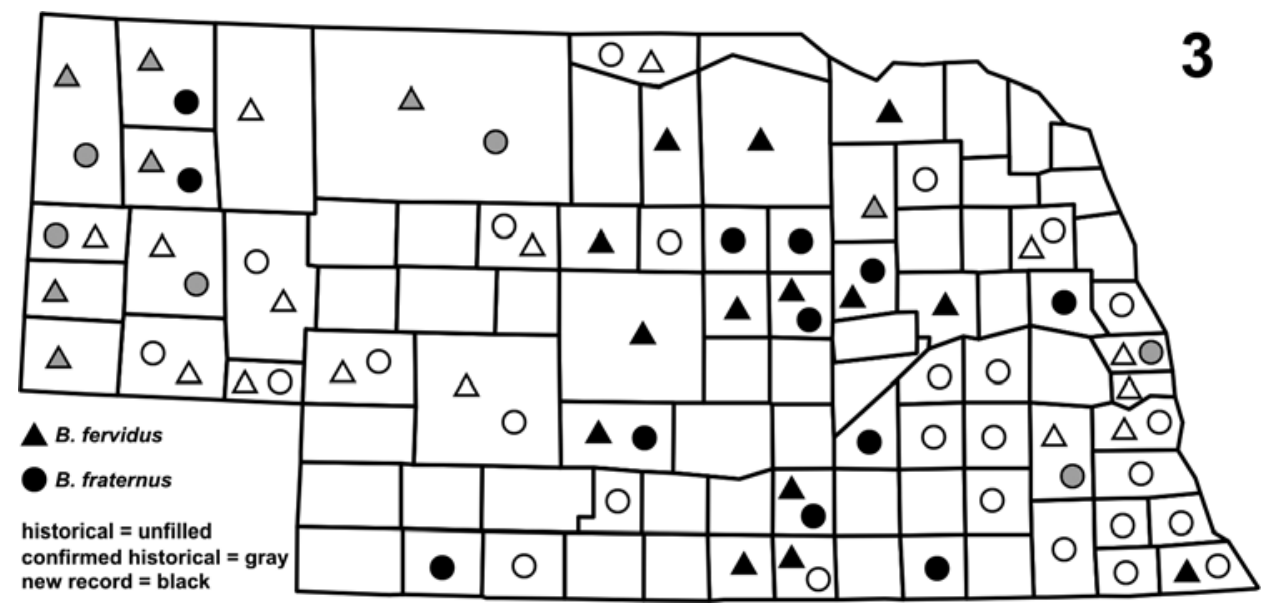

Figs. 1-8. Continued.

remote areas of Sioux, Scottsbluff, and Banner counties, the only locations where some species were collected in previous surveys.

\section{Results}

A total of 3219 specimens were collected as a part of this study. Of those specimens, 1306 were collected by cooperating partners. The remainder of the specimens were collected by the authors. Nineteen of the 20 species reported by LaBerge and Webb (1962) were collected during this study with Bombus morrisoni (Cresson) being the only uncollected species. A total of 107 new county records were established as a part of this project (see Figs. 1-10). The distribution of many species was expanded during this study, most notably that of Bombus huntii (Greene), Bombus bimaculatus (Cresson), and Bombus vagans (Smith). No intergrade specimens between Bombus nevadensis nevadensis

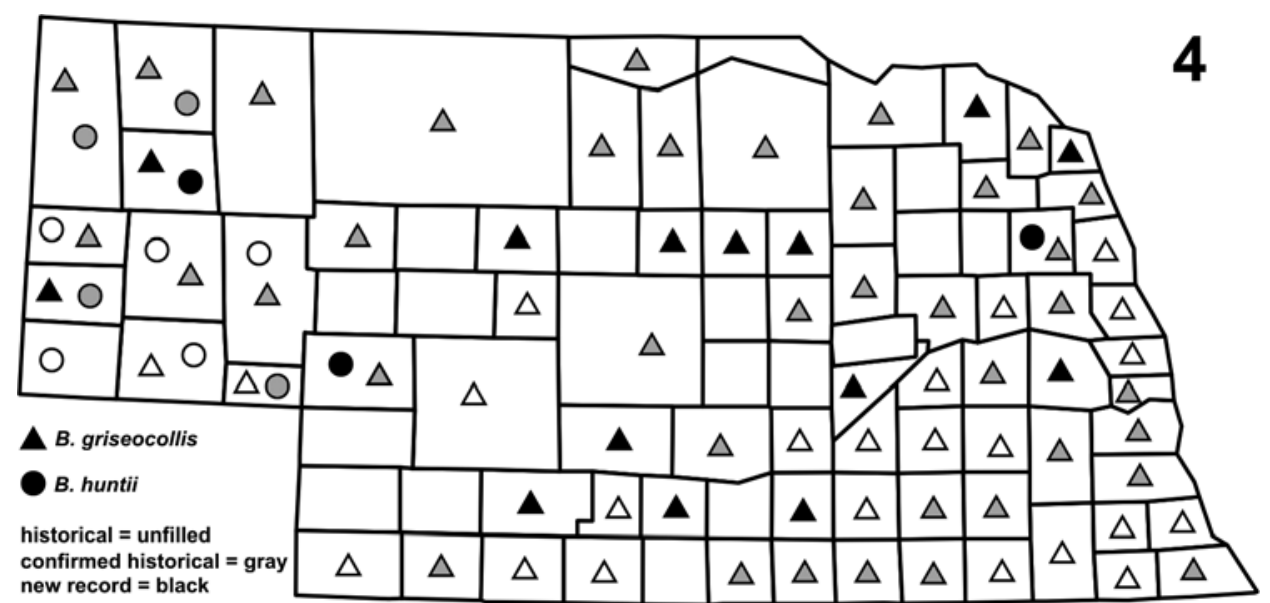

Figs. 1-8. Continued. 


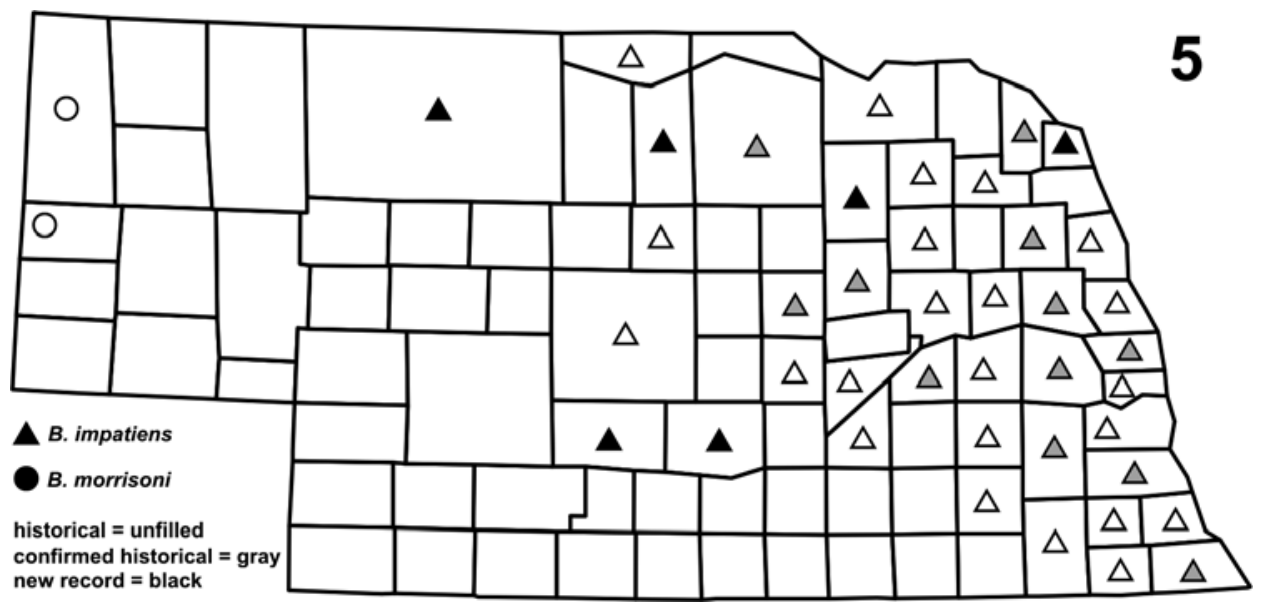

Figs. 1-8. Continued.

(Cresson) and Bombus nevadensis auricomus (Robertson), as reported by LaBerge and Webb (1962), were collected during this study. One male specimen of Bombus flavifrons (Cresson) was collected in Lexington in June of 2000 by a student at Lexington High School (identification confirmed by R. Brooks). Bombus flavifrons was not included in LaBerge and Webb's (1962) annotated list. The authors traveled to Lexington in June of 2001 to attempt to collect additional B. flavifrons specimens but were unsuccessful. We consider the occurrence of $B$. flavifrons tenuous until additional specimens are procured, and thus have not included B. flavifrons in the maps of species known to the state.

\section{Discussion}

No specimens of $B$. morrisoni (Cresson) were collected during this study. This species was reported by LaBerge and Webb (1962) to have been collected in 1912 in Sioux and

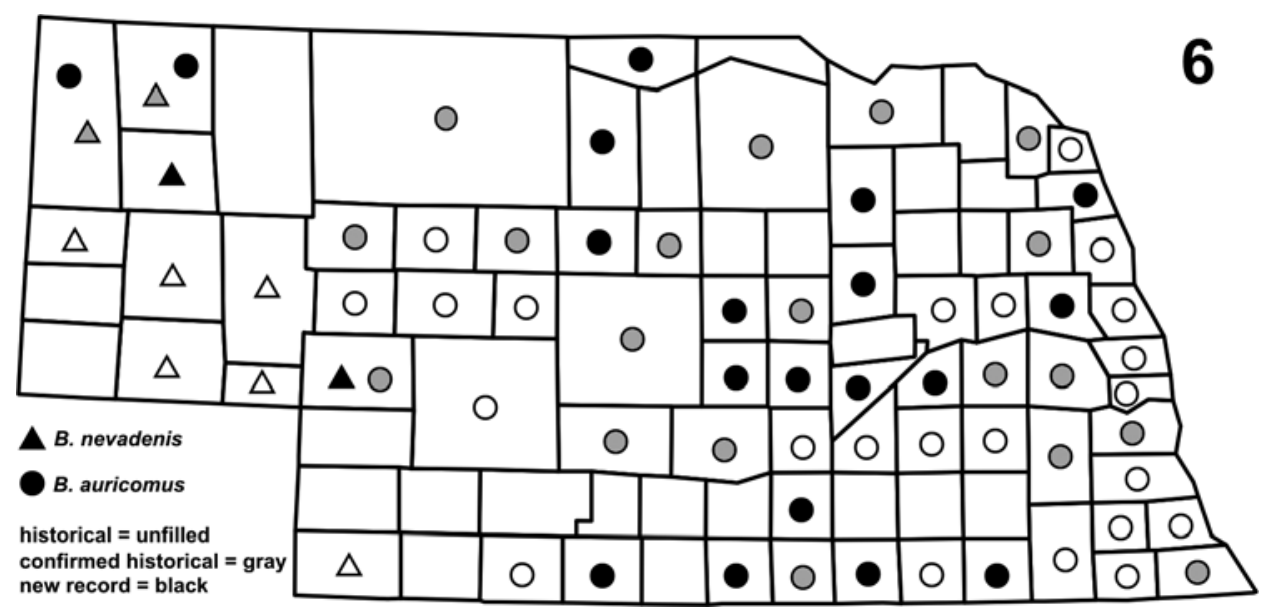

Figs. 1-8. Continued. 


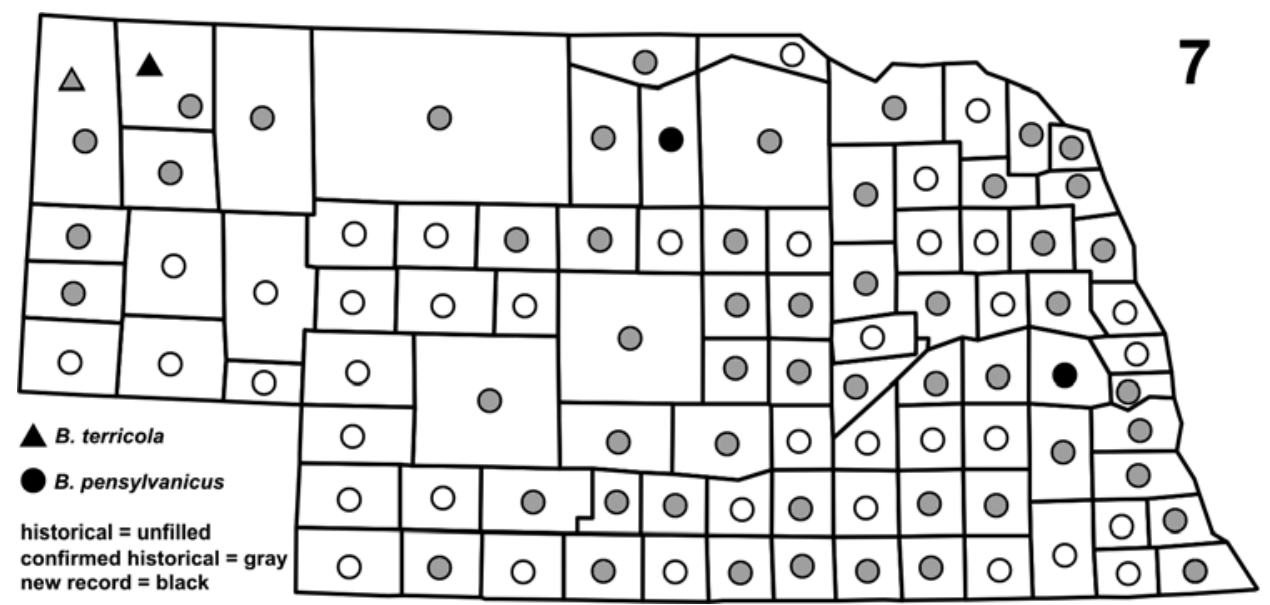

Figs. 1-8. Continued.

1913 in Scotts Bluff counties, respectively. The project participants did collect bumble bees in Scotts Bluff and Sioux counties as a part of this study, but did not collect B. morrisoni. Further surveys within the range reported by LaBerge and Webb (1962) should be conducted to determine whether it still persists in the state.

One female B. huntii was collected by the authors in West Point, Cuming County, 20 August 1999. This is an interesting record as the nearest known population is found in western Keith county, approximately 265 miles away. Swenk (1907) reported one male Bombus rufocinctus (Cresson) collected in West Point. The nearest known B. rufocinctus population is also found in western Nebraska. Swenk (1907) also listed B. nevadensis nevadensis being collected in West Point. The occurrence of these typically western species suggests there is at least a pocket of western species that occur in the West Point, Nebraska area. Further collections should be conducted to determine if B. rufocinctus and B. nevadensis nevadensis still exist in the area.

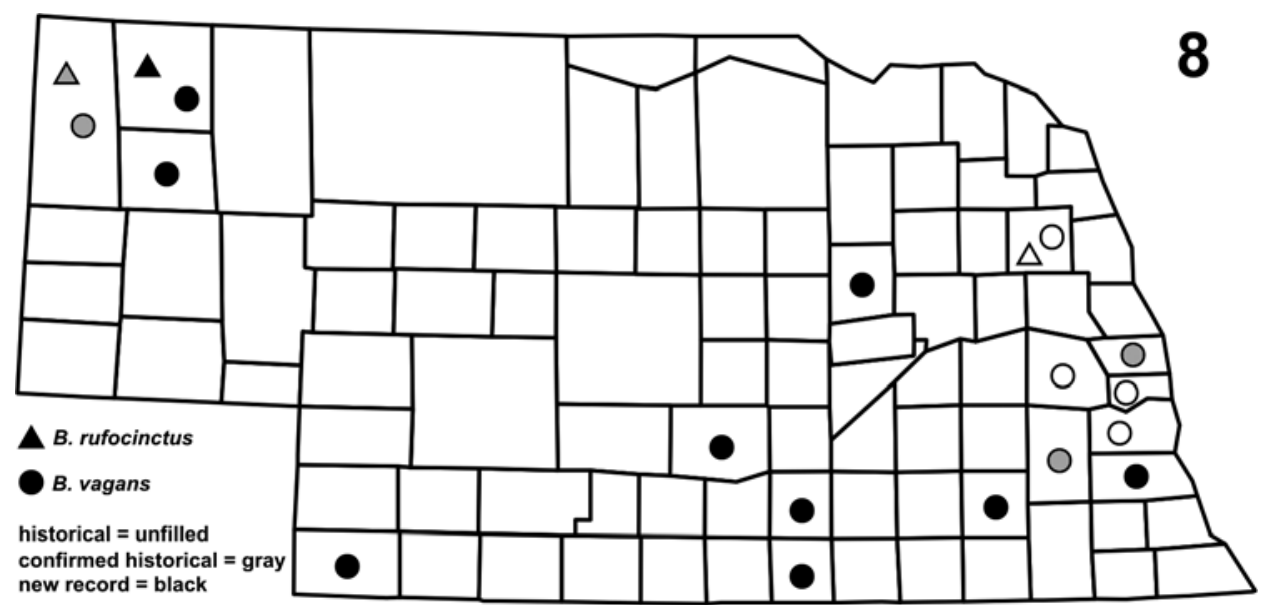

Figs. 1-8. Continued. 


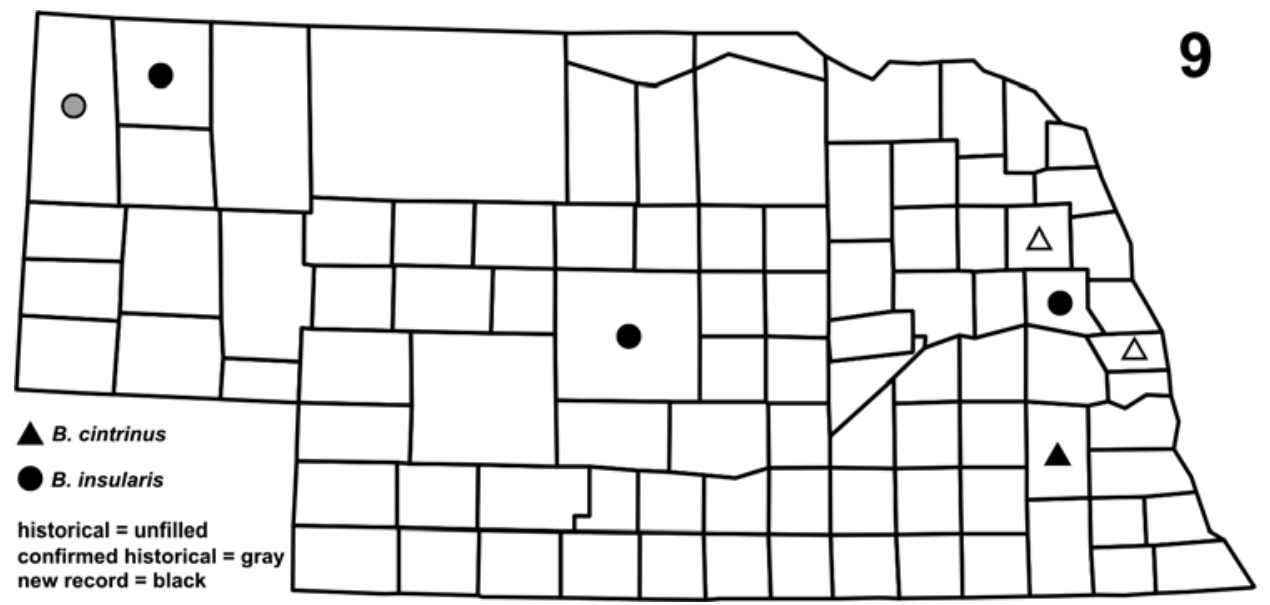

Figs. 9-10. Historical = county records presented in Swenk (1907) and LaBerge and Webb (1962), confirmed historical $=$ those country records reported in Swenk (1907) and LaBerge and Webb (1962) and recollected in this study, new record = new county records established by this study. Nomenclature follows Michener's (2000) and Williams's (2005) grouping of the genera Bombus and Psithyrus into a single genus, Bombus.

During the project several specimens of $B$. nevadensis nevadensis and $B$. nevadensis auricomus were collected in their overlapping ranges as reported by LaBerge and Webb (1962). Since no intergrades were collected during our study, we feel this provides further support to the argument (Scholl et al., 1992; Williams, 2005) that B. n. nevadensis and $B$. n. auricomus are separate species. Accordingly we have reported B. nevadensis and B. auricomus as separate species in Fig. 6.

While we collected bumble bees throughout the state, we did not collect extensively in Kimball, Cheyenne, Deuel, Dundy, Chase, and Perkins Counties. Attempts were made to recruit partner schools in this part of the state but were unsuccessful. Given the proximity of these counties to Colorado, there is the potential that these areas may hold species not previously recorded in Nebraska.

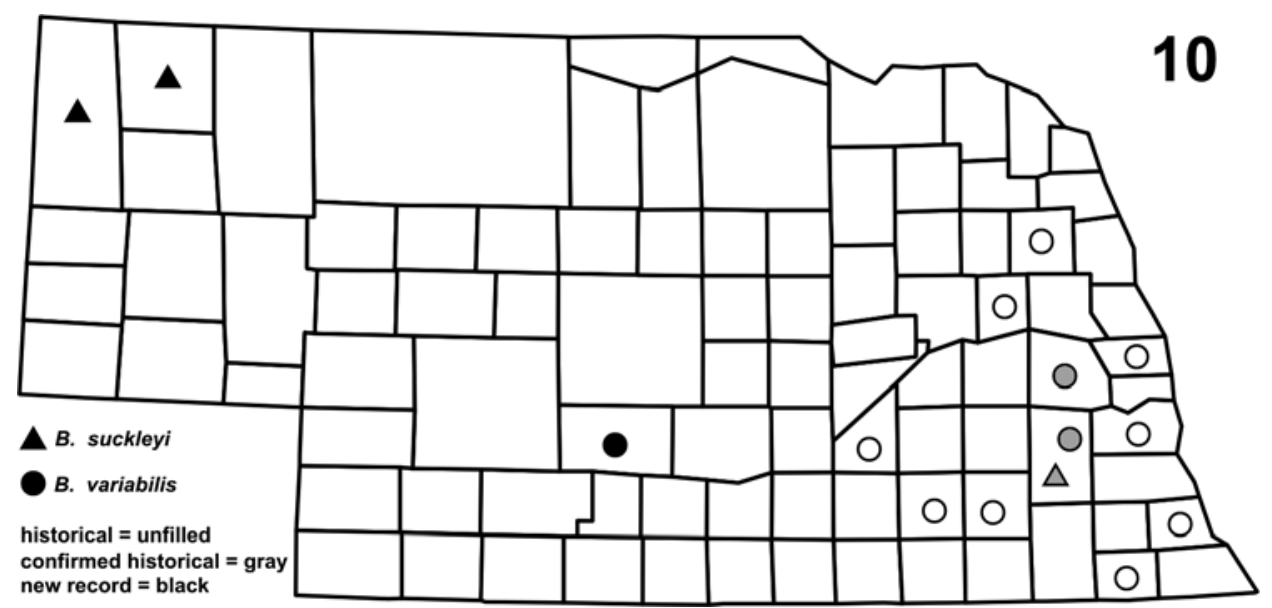

Figs. 9-10. Continued. 


\section{Acknowledgements}

The authors thank Albion High School, Ashland-Greenwood HS, Clearwater HS, Kearney HS, Lincoln Public Schools Science Focus HS, Litchfield HS, Lexington HS, Newman-Grove HS, Wisner-Pilger HS, North Bend HS, Spalding Academy, Wakefield HS, Wildcat Hills Nature Center, Randy Lawson of Chadron State College, Wyatt Hoback of University of Nebraska-Kearney, Matt Paulsen of the University of Nebraska State Museum, and Gary Hein of the Panhandle Research and Extension Center for submitting specimens to this study. We also thank Rob Brooks, formerly of the University of Kansas Snow Museum, for his training in bumble bee identification and for the identification of the B. flavifrons specimen. We also thank Steve Spomer of the UNL Department of Entomology and Bret Ratcliffe of the University of Nebraska State Museum for their initial comments and review of this manuscript. This paper is number 14573 of the journal series of the Agricultural Research Division, University of Nebraska-Lincoln. Mention of proprietary products does not constitute an endorsement by the authors or the University of Nebraska.

\section{Literature Cited}

Golick, D. A., and M. D. Ellis. 2000. Bumble Boosters: A Guide to Identifying Nebraska Bumble Bee Species. University of Nebraska Cooperative Extension EC 00-1564-S.

Golick, D. A., and M. D. Ellis. 2003. Bumble Boosters: doing science as a community of learners. American Entomologist 49(2), 76-80.

LaBerge, W. E., and M. C. Webb. 1962. The Bumblebees of Nebraska. Research Bulletin, University of Nebraska College of Agriculture, Agricultural Experiment Station 205: 33.

Michener, C. D. 2000. The Bees of the World. John Hopkins University Press, Baltimore, Maryland. xiv $+[1]+$ 913 pp.

National Agricultural Statistics Service (NASS). 2005. Agricultural Statistics Data Base. http://www.usda.gov/ nass/.

Scholl, A., R. W. Thorp, R. E. Owen, and E. Obrecht. 1992. Specific distinctness of Bombus nevadensis Cresson and B. auricomus (Robertson) (Hymenoptera: Apidae) enzyme electrophoretic data. Journal of the Kansas Entomological Society 65:134-140.

Swenk, M. H. 1907. The bees of Nebraska. Entomological News 18:293-300.

Williams, P. H. The Natural History Museum Web Site: Bombus http://www.nhm.ac.uk/entomology/bombus/ index.html. Accessed. (March 20, 2005). 